УДК 82I.I6I.I

ББК $83.3(2 \mathrm{Poc}=\mathrm{Pyc}) 6$
ОБРАЗ НЕСТОРА МАХНО НА СТРАНИЦАХ

ТРИЛОГИИ А.Н.ТОЛСТОГО

«ХОЖДЕНИЕ ПО МУКАМ»: ДОКУМЕНТЫ

И МАТЕРИАЛЫ

\author{
(C) 2017 г. Г.Н. Воронцова \\ Институт мировой литературы \\ им. А.М. Горького Российской академии наук, \\ Москва, Россия \\ Дата поступления статьи: о5 сентября 2017 г. \\ Дата публикации: 25 декабря 2017 г. \\ DOI: IO.22455/2500-4247-20I7-2-4-250-269
}

Статья подготовлена при финансовой поддержке Российского фонда фундаментальных исследований (РФФИ). Проект № I7-84-огоо5а (и)

Аннотация: Основное внимание в статье уделено анализу документальных источников образа Нестора Ивановича Махно в трилогии А.Н. Толстого «Хождение по мукам», как опубликованным (творческие записи в составе записных книжек), так и ранее не публиковавшимся. К числу последних относятся выписки писателя из «Дневника жены Махно» и Акт о расстреле махновцами атамана Н.А. Григорьева от 28 июля I9I9 г. Документ под названием «Дневник жены Махно» неоднократно цитировался в советских изданиях 1920-х гг., что вызвало негативную реакцию как самого Махно, так и идеолога махновского движения П.А. Аршинова, объявившего «Дневник» фальшивкой. Однако гражданская жена вождя украинских повстанцев, Г.А. Кузменко, в беседе с историком С.Н. Семановым в конце г960-х гг. признала подлинность документа. Более всего знакомство Толстого с «Дневником» проявилось в завершающей книге трилогии «Хождение по мукам», романе «Хмурое утро», при характеристике поведения Махно накануне похода на Екатеринослав. Несомненный интерес представляет собой и публикуемый в составе статьи Акт о расстреле атамана Н.А. Григорьева из архива Толстого, с которым связан случай откровенного отказа писателя от достоверных, документально подтвержденных сведений. Несмотря на то что в Акте изложена версия об убийстве Григорьева окружением Махно, писатель посчитал необходимым завершить сюжет, связанный с махновским движением, жирной точкой: уходит вождь украинского повстанческого движения со страниц трилогии непосредственным убийцей мятежного атамана, что, видимо, соответствовало представлениям Толстого об этом человеке, ставшем литературным героем.

Ключевые слова: А.Н. Толстой, трилогия «Хождение по мукам», Нестор Махно, архив, документы и материалы, история создания произведения.

Информация об авторе: Галина Николаевна Воронцова - кандидат филологических наук, старший научный сотрудник, Институт мировой литературы им. А.М. Горького Российской академии наук, ул. Поварская, д. 25 а, І2Іо69 г. Москва, Россия.

E-mail: voroncova.96@mail.ru 


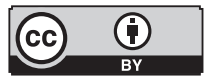

This is an open access article distributed under the Creative Commons Attribution 4.0 International (CC BY 4.0)

\section{THE IMAGE OF NESTOR MAKHNO IN THE PAGES OF ALEXEY N. TOLSTOY'S TRILOGY THE ROAD TO CALVARY: DOCUMENTS AND MATERIALS}

\author{
(C) 20I7. G.N. Vorontsova \\ A.M. Gorky Institute of World Literature \\ of the Russian Academy of Sciences, Moscow, Russia \\ Received: September 05, 2017 \\ Date of publication: December 25, 2017
}

Acknowledgements: The article was implemented with the financial support of the Russian Foundation for Basic Research (RFBR). Project № I7-84-0I005a(Ц).

Abstract: This article examines documentary sources of the image of Nestor Ivanovich Makhno in Alexey N. Tolstoy's trilogy The Road to Calvary; it bears on the materials that are both published (Tolstoy's notebooks) and hitherto unpublished. Among the latter, there are Tolstoy's notes from The Diary of Makhno's Wife and the execution record of ataman N.A. Grigoriev shot by the Makhnovists on July 28, I9I9. The document entitled The Diary of Makhno's Wife was repeatedly quoted in Soviet publications of the I920s which caused a negative reaction on behalf of both Makhno and P.A. Arshinov, the ideologist of the Makhnovist movement who claimed the diary to be fake. However, G.A. Kuzmenko, Makhno's civil wife, recognized the authenticity of the document in a conversation with a historian S.N. Semanov in the late I960s. The traces of Tolstoy's acquaintance with the diary may be found in the final book of the trilogy The Road to Calvary, a novel Gloomy Morning where he describes Makhno's behavior before the march on Yekaterinoslavin. Drawing details from the document, reconstructing a general picture on its basis and adding imaginary details, the author thus gave his own assessment of the diary. Equally interesting is Grigoriev's execution record that is preserved in Tolstoy's archive. It is the evidence of the author's open refusal to follow reliable, documented information. Despite the fact that Grigoriev was shot by Makhno's allies, the author makes Makhno himself commit the crime. The leader of the Ukrainian rebel movement leaves the pages of the trilogy as the immediate assassin of the insurgent ataman, and the novel's climax thus reflects Tolstoy's attitude to his literary character.

Keywords: A.N. Tolstoy, trilogy The road to Calvary, Nestor Makhno, archive, documents and materials, the history of the trilogy.

Information about the author: Galina N. Vorontsova, PhD in Philology, Senior Researcher, A.M. Gorky Institute of World Literature of the Russian Academy of Sciences, Povarskaya 25 a, I21069 Moscow, Russia.

E-mail:voroncova.96@mail.ru 
Среди реальных исторических лиц, героев трилогии А.Н. Толстого «Хождение по мукам», выделяется Нестор Иванович Махно, возглавивший в годы Гражданской войны крестьянское повстанческое движение на Украине. Ему посвящено немало страниц романов «Восемнадцатый год» и «Хмурое утро», созданных автором в конце г920-х и І930-х гг. после возвращения из эмиграции в советскую Россию.

Впервые с именем Махно читатель встречается в четвертой главе романа «Восемнадцатый год». Его упоминает Семен Красильников в разговоре с братом Алексеем: «Про Махно, Нестора Ивановича, бродят слухи, будто бы шайка у него человек в двадцать пять головорезов, - налетают на экономии» $[8$, с. 365].

Летом І9І8 г., в лагерь махновцев попадает Катя Булавина, так и не доехавшая из Ростова до Екатеринослава, а затем, несколько месяцев спустя, дезертировавший из Добровольческой армии Вадим Рощин. Катя сначала слышит («Резкий голос, с запинкой, с бабьим оттенком крикнул повелительно» [8, с. 438]), а потом и видит Махно: «Это был маленький человек <...> Прямые каштанового цвета длинные волосы падали ему на узкие, как у подростка, плечи. Черный суконный пиджак был перекрещен ремнями снаряжения, за кожаным поясом - два револьвера и шашка, ноги - в щегольских сапогах со шпорами - скрещены под стулом. Покачивая головой, отчего жирные волосы его ползли по плечам, он торопливо писал, перо брызгало и рвало бумагу <...> Катя с содроганием увидела наконец лицо этого маленького человека в черном полувоенном костюме. Он казался переодетым монашком. Из-под сильных надбровий, из впадин глядели на 
Катю карие, бешеные, пристальные глаза. Лицо было рябоватое, с желтизной, чисто выбритое - бабье, и что-то в нем казалось недозрелым и свирепым, как у подростка. Все, кроме глаз, старых и умных» [8, с. 439-440].

Этот созданный писателем портрет со снижающими облик героя чертами («маленький человек», «узкие, как у подростка, плечи», «жирные волосы», «бабье» лицо) и одновременно указанием на неоднозначность, противоречивость характера персонажа («старые» и «умные» глаза) служит камертоном к изображению Махно в трилогии и интерпретации связанных с ним событий. В дальнейшем, рисуя его облик при встрече и беседе с Рощиным, Толстой усилит то, что несколько месяцев назад удалось разглядеть Кате, но и подчеркнет феноменальность пути, пройденного атаманом от главаря шайки в «двадцать пять головорезов» до вождя повстанческой армии, союза с которой ищут и белые и красные:

Махно снял фуражку, - лоб его был мокрый. Он опять сел на диванчик. Ему не хватало четок, чтобы совсем походить на изувера-послушника.

- Сядьте, пожалуйста. - Он махнул длинной рукой, указывая Рощину на стул. - Если вас и придется расстрелять, все равно - позор, позор оскорблять человеческое достоинство. Возьмите папиросу, закуривайте. Вы разведчик?

- Нет, - глухо ответил Рощин, усмехнулся и взял папиросу.

- Добровольческий офицер?

- Я дезертировал. Кончил с этим. Вы же мне все равно не верите, чего я буду рассказывать...

- Мне не врут, - сказал Махно тем же высоким, особенным голосом, который трудно было бы записать на нотные знаки. Рощину он показался похожим на клекот. - Мне не врут, - повторил он, и глаза его, сухие и немигающие, выражали такое превосходство воли, что трудно было глядеть в них. Навертывались слезы у того, кто хотел бы выдержать этот взгляд [9, с. I47].

Хронологически в трилогии «Хождение по мукам» показан лишь небольшой период махновщины с лета до конца I9I8 г., включая взятие Екатеринослава и уход из города. Однако сохранившиеся наброски произведения свидетельствуют, что первоначально Толстой планировал продолжить повествование о Махно и далее. В одной из творческих записей его имя упо- 
минается в перечне событий г919 г.: «Москва. Пермь. Общие события. Полк Горы выступает против Григорьева. Венгерская революция... Григорьев потрясает Украину. Махно и Григорьев... (Убийство). Наступление Деникина. Конец разгрома под Касторной» [2, с. 316]. Еще одна запись, размещенная под датой «І9-й год», указывает на интерес писателя ко второму походу махновцев на Екатеринослав осенью І9І9 г.: «Махно и Полонский. Пол<онский> брал Екатериносл<ав>. Махно пьянствовал» [2, с. 293].

Приведенные записи, наряду с другими, в составе записных книжек Толстого были опубликованы Л.И. Толстой и Ю.А. Крестинским в 1965 г. в семьдесят четвертом томе «Литературного наследства». По мнению публикаторов, в них «преобладают свидетельства современников: непосредственные записи рассказов участников тех или иных событий, или же выписки из их воспоминаний, а также данные, почерпнутые из различных исторических документов» [2, с. 277-278]. К таковым следует, вероятно, отнести записи о Махно, связь которых с текстом произведения очевидна: «Глядит в упор бешенным взглядом. Тщеславие. Живучий как сколопендра» [2, c. 286]; «Махно - рябой. Русый. Голос хриплый, бабий» [2, с. 286]; «Махно на велосипеде» [2, с. 315]. Однако они не исчерпывают всего сохранившегося в архиве писателя комплекса материалов, положенных в основу образа вождя украинских повстанцев. Материалы эти многочисленны и разнообразны: от книг участников повстанческого движения с подчеркиваниями Толстого, выписок из исторических трудов и периодики I9I8-1920 гг. до подлинных документов времен Гражданской войны. К некоторым из них мы и хотим обратиться.

Среди выписок, связанных с Нестором Махно, обращает на себя внимание текст, озаглавленный «Из дневника жены Махно. Жена Махно - Гаенко, сельская учительница, убита в бою»:

Мы были еще в постели, как какой-то хлопчик принес нам поесть. Характерно: Все хуторяне едят постное; нам же, зная, что мы едим скоромное, какая-то хозяйка напекла скоромных блинов и наварила крошенки. Только что мы сели закусывать, как какая-то молодица принесла нам свежих бубликов. Через полчаса какая-то девушка принесла миску сметаны...

2 марта (г9 г.) ...ночью сегодня хлопцы взяли 2 миллиона денег и сегодня всем выдано гооо рубл<ей>. 
6 марта ...выехали на Новоселовку. Остановились на прежней квартире. Хозяин тут очень симпатичный человек. Сегодня он нагнал самогону и угостил нас.

7 марта. С Новоселовки батько начал пить. В Варварке совсем напился, как он, так и его помощник Каретник. Еще в Шагарове батько начал уже дурить, срамно ругался на всю улицу, кричал, как сумасшедший, ругался в хате при малых детях и женщинах ${ }^{\text {. } . ~ С е л ~ н а ~ л о ш а д ь ~ в е р х о м ~ и ~ п о е х а л ~ н а ~ Г у л я и ̆ ~}$ Поле. По дороге чуть не упал в грязь.

Каретник же начал дурить по-своему, подошел к пулеметам и начал стрелять то с одного, то с другого. Засвистали пули низко над хатами.

Приехали в Гуляй Поле. Тут под пьяную руку батько стал вытворять что-то невозможное. Кавалеристы (черная сотня) начали бить нагайками и прикладами всех бывших партизан наших, каких только встречали на улицах.

I3 марта. Батько и сегодня выпил. Говорил очень много. Бродит пьяный по улице с гармошкой и танцует. С каждым лается срамными словами ${ }^{2}$. Наговорившись и натанцевавшись - заснул.

I4 марта. Сегодня приехали в Большую Михайловку. Убили здесь одного коммуниста ${ }^{3}$.

Документ под названием «Дневник жены Махно» был известен с начала I920-х гг. и по крайней мере трижды цитировался в различных изданиях первого десятилетия советской власти: книгах Р.П. Эйдемана «Борьба с кулацким повстанчеством и бандитизмом» (Харьков: Изд. Политуправления всех вооруженных сил Украины, г92г. С. 47-49), Я.А. Яковлева «Русский анархизм в Великой Русской Революции» (М.: Гос. изд., I92I. С. 29) и М.И. Кубанина «Махновщина. Крестьянское движение в Степной Украине в годы Гражданской войны» (Л.: Прибой, [І927]. С. II8, I45-I46). При этом дважды (у Эйдемана и Яковлева) имя жены Махно названо неверно - Феодора Лукьяновна Гаенко, - в то время как гражданской супругой вождя украинских повстанцев с г919 г. была Галина (Агафья) Андреевна Кузьменко (I892-I978), личность в среде махновцев довольно известная. Закончив

I Текст «Еще в Шагарове <... при малых детях и женщинах» отчеркнут слева красным карандашом.

2 Текст «Бродит пьяный по улице с гармошкой и танцует. С каждым лается срамными словами» подчеркнут красным карандашом.

3 ОР ИМЛИ. Ф. 43. Оп. г. Ед. хр. г2г. Л. І-4. 
учительскую семинарию, она работала в земской школе Гуляй Поля, а с I919 г. принимала активное участие в повстанческом движении. На момент публикации фрагментов «Дневника», в г920-х гг., находилась вместе с Махно в эмиграции, сначала в Румынии и Польше, с 1925 г. в Париже. Драматична дальнейшая судьба Галины Андреевны. В годы Второй мировой войны она была вывезена на принудительные работы в Германию. После прихода туда советских войск оказалась на родине, где была приговорена к десяти годам заключения. После освобождения жила в Казахстане [4, с. 9ог].

О происхождении «Дневника» рассказывал Р.П. Эйдеман: «29 марта І920 года во время разгрома махновской банды в Гуляй Поле отрядом 42-й дивизии была убита жена Нестора Махно <...> В ее походной сумке был найден дневник, в котором она вела записи с г9-го февраля по 28 марта I920 года. В том дневнике она день за днем рассказывает о жизни банды, Махно, своей» [Іо, с. 46-47].

Во всех трех случаях (у Эйдемана, Яковлева и Кубанина) мы имеем дело не только с разными записями «Дневника», но и различными версиями текста документа, что, видимо, было обусловлено в каждом конкретном случае особенностями перевода оригинала, выполненного на украинском языке. Датировка записей в этих публикациях подчас ошибочна. Так, Эйдеман цитирует записи от 23, 24 и 25 февраля, 6, 7, I2, I3, I4 и I7 марта I920 г. При этом под 23 февраля он воспроизводит только часть записи, а под 7 марта помещает записи от 7-го марта. Яковлев, в свою очередь, приводит записи от I, 2, 7 и I4 марта, ошибочно датируя запись от 2 марта II марта и объединяя в одну записи от 7 и 8 марта. Кубанин ограничивается небольшими цитатами из записей от 23, 24 и 25 февраля и I6 марта, также путаясь в датах (например, записи от 23 и 25 февраля он датирует 23 и 25 марта). Кроме того, Кубанин неверно относит дневниковые записи к г92I г., однако часть их приводит в главе своей книги под названием «Борьба Махно с советской властью в г 920 г.».

Говорить о полноте записей и их датировке стало возможным после публикации «Дневника», в том числе в составе тома «Крестьянское движение на Украине. І9г8-г921. Документы и материалы» [4, с. 828-838] по переводу с украинского языка, сделанному в І923 г. На титульном листе документа есть надпись: «Дневник жены Нестора Махно Галины Кузьменко, захваченный в бою 29 марта I920 г. у Гуляй-Поля комбригом I24, 42-й ди- 
визии, І 3 армии (Перевод с украинского). Перевел переводчик информационно-статистической части разведывательного отдела штаба Украинского военного округа тов. Шор г923 года 30 января» [4, с. 828]. В примечаниях сказано, что ныне машинописный подлинник перевода хранится в Центральном государственном военном архиве (Ф. І407. Оп. І. Д. 9Іо), а его машинописная копия - в Центральном государственном архиве высших органов власти Украины (Ф. 3204. Оп. 2. Д. І2). Сам же «Дневник», т. е. его подлинник на украинском языке, находится на хранении в Государственном архиве Российской Федерации 4 .

Исходя из приведенных сведений, с большой долей вероятности можно предположить, что с подлинником «Дневника» имел дело его первый публикатор Роберт Петрович Эйдеман, активный участник Гражданской войны, будущий комкор (I935), в июне-июле г92о г. командовавший той самой I3-й армией, в состав которой входила 42-я дивизия, бойцы которой сражались с махновцами у Гуляй Поля в марте г920 г. На подлинник «Дневника», как на источник приведенных цитат, ссылается и Кубанин, указывая местом его хранения в конце г920-х гг. Харьковский Архив Революции (фонд Совнаркома УССР, дело I44). Однако был ли это действительно подлинник или перевод «Дневника» неизвестно.

Цитирование документа в советских изданиях тогда же привлекло внимание находившегося в эмиграции Нестора Махно, выступившего с резкой критикой в адрес как самих приводившихся записей, так и их публикаторов:

Как известно, у большевиков, судя по их заявлениям, имеется дневник «жены Махно». Дневником этим они пользуются так, как это оправдывается их целями и задачами, связанными с тем, чтобы как можно чернее представить перед массами махновщину и ее руководителей, как можно грязнее запятнать ее и, тем самым нанести ей, прежде всего и главным образом, удар с идеологической стороны, как революционно-освободительному антигосударственническому движению украинских народных масс.

Так, например: некий Я. Яковлев, автор известной по своей лживости, направленной против анархизма, брошюрки «Анархизм в Великой Русской 
Революции» пользуется этим дневником как дневником жены Махно - Феодоры Гоенко. А М. Кубанин меняет годовую дату этого же самого дневника и пользуется им, как документом жены Махно - Галины Кузьменко.

Такое, поистине антиреволюционное, партийно-жульническое поведение большевиков в их передержках и разного рода подтасовках в данном вопросе, с данным «дневничком», определенно говорит за то, что большевики, получив «дневничек» этот в свои руки, менее всего думали о его глупом содержании, о том, чтобы выяснить, - кому он в действительности принадлежит, кто его автор. Они решили использовать его худшие стороны со своими красками, поэтому, не стыдясь самих себя, постарались выдумать ему автора в лице, наиболее близком к Махно. Не зная имени и фамилии жены (по их выражению) Махно, они напали на имя Феодоры Гоенко и, экспромтом, окрестив ее женой Махно, приписали ей этот злополучный «дневник» <...>

Однако, вернемся к существу самого «дневничка» или, вернее, к выдержкам из него, которые М. Кубанин, следуя за Яковлевым и другими своими товарищами, представляет нам в своей книге «Махновщина». О них именно я считаю своим долгом кое-что сказать. Первое. Я категорически заявляю свое опровержение того, что большевиками цитируется, якобы из этого же «дневничка», что будто бы я, руководя таким грандиозным движением, как революционная махновщина, имел привычку напиваться до пьяна, ходить по селу или деревне с гармошкой, наигрывая на ней на утеху себе и жителям. Я на гармонии не играю и никогда в жизни не играл, хотя и люблю послушать ее, когда на ней играет хороший мастер. Еще с большей категоричностью я опровергаю то, что (опять-таки согласно дневничка) большевики утверждают, будто бы повстанцы махновцы - эти безымянные революционные борцы - добровольцы в армии движения Махновщины - получали жалование по гооо руб. или вообще жалование <...>

Во всяком случае, я лишний раз подчеркиваю то, что эти положения этого злополучного «дневничка» «жены» Махно ни в основе, ни в деталях своих, не содержат никакой истины, - они ложны [3, с. 28-31].

Еще более резко высказался по поводу цитирований «Дневника» один из сподвижников Махно П.А. Аршинов. В примечании к своей работе «История махновского движения (гіг-і92г гг.)» он писал: «Начиная с I920 г., большевики много писали об отрицательных личных сторонах Max- 
но, ссылаясь на дневник якобы его жены, некоей Федоры Гаенко, захваченный будто во время одного боя. Жена Махно, Галина Андреевна Кузьменко, живет с ним с г9г8 г. Никогда она личного дневника о махновском движении не вела и не теряла (курсив наш. - Г.В.). Следовательно, ссылка на такой дневник есть обычная ложь власти, не постеснявшейся прибегнуть к фальсификации» [I, с. 2I9].

Точка в этой истории была поставлена лишь в конце г96о-х гг., когда советский историк С.Н. Семанов, тогда сотрудник Института истории АН СССР в Ленинграде, осенью І968 г. встретился и побеседовал с самой Галиной Андреевной Кузьменко, проживавшей на тот момент в городе Джамбуле (Казахстан). Впоследствии он рассказал об этой встрече и об авторстве «Дневника»:

Дневник этот, написанный в тетради на украинском языке, был захвачен красными в одной из мелких и бесконечных стычек с махновцами весной I920-го, тогда же частично опубликован в советской печати. Сперва приписывался этот документ некоей Феодоре Гаенко, называемой женой Махно, позже авторство адресовали правильно - Галине Кузьменко. В чем тут дело, почему возникла разноголосица? Это был один из первых вопросов, с которым я обратился к Галине Андреевне, и получил от нее обстоятельную справку.

- Нестор очень хотел, чтобы история движения <...> была записана. При штабе был один гимназист, которого специально держали для ведения дневника <...> Я тоже вела дневник, тетрадь одолжила у Фани Гаенко, она была молодая женщина, любовница Льва Задова, на первой странице тетради была написана ее фамилия, а всю тетрадь записала я. Как-то мы с Фаней ехали по дороге в повозке, когда не помню, но было холодно, я была в шапке, появились красные кавалеристы, нас не тронули, но выпрягли лошадей, оставили на своих, загнанных. Чемодан с вещами был на другой повозке, его забрали, а там лежал дневник. Потом в какой-то советской газете появилась статья о дневнике жены Махно Феодоры Гаенко. Аршинов сердито опровергал, но на самом-то деле дневник вела я [6, с. 44-45].

В перестроечные годы в своей книге о Махно Семанов опубликовал «Дневник» почти полностью по переводу, полученному от Ильи Альтмана, сотрудника Центрального архива Октябрьской революции (ныне ГАРФ). За 
пределами публикации остались лишь три страницы, где подробно рассказывалось о том, как автор «Дневника» «вымокла в дороге» [6, с. 45].

Сравнительный анализ текста выписок Толстого и публикаций «Дневника» I920-х гг. показал, что ближе всего они, по объему и по содержанию, к записям, приведенным в книге Эйдемана «Борьба с кулацким повстанчеством и бандитизмом», хотя и имеют с ними ряд разночтений. Так, выписки Толстого начинаются с недатированной писателем записи от 28 марта, которой у Эйдемана нет. Толстой, видимо ошибочно, после даты «2 марта» в скобках проставляет «I9 г.», в то время как «Дневник» относится к 1920 г. Другие разночтения касаются содержания записей. В качестве примера сошлемся на одну из них, от 7 марта, в выписках Толстого и книге Эйдемана:

\section{А.Н. Толстой:}

C Новоселовки батько начал пить. В Варварке совсем напился, как он, так и его помощник Каретник. Еще в Шагарове батько начал уже дурить, срамно ругался на всю улицу, кричал, как сумасшедший, ругался в хате при малых детях и женщинах. Сел на лошадь верхом и поехал на Гуляй Поле. По дороге чуть не упал в грязь.

Каретник же начал дурить по-своему, подошел к пулеметам и начал стрелять то с одного, то с другого. Засвистали пули низко над хатами. Приехали в Гуляй Поле. Тут под пьяную руку батько стал вытворять что-то невозможное. Кавалеристы (черная сотня) начали бить нагайками и прикладами всех бывших партизан наших, каких только встречали на улицах ${ }^{\mathrm{T}}$.

\section{Р.П. Эйдеман:}

C Новоселки батько начал пить. В Варварке совсем напился, как он, так и его помощник Каретник. Еще в Варваровке батько начал дурить, ругался срамными словами на всю улицу, кричал, как сумасшедший, ругался и в хате при маленьких детях и при женщинах. Сел верхом на лошаденку и поехал в Гуляй Поле. По дороге чуть не упал в грязь. Каретник же (замкомандарма I-й махновской) начал дурить по-своему, подошел к пулеметам и начал стрелять то с одного, то с другого. Засвистели пули низко над хатами. Приехали в Гуляй Поле. Здесь под пьяной командой Каретника и батьки начали вытворять что-то невозможное. Кавалеристы (черная сотня) начали бить нагайками и прикладами всех бывших партизан наших, каких только встречали на улицах [ıо, с. 48].

Учитывая все это, можно предположить, что писатель имел дело с одним из существовавших на тот момент переводов «Дневника», а не с пе- 
чатными публикациями документа. Это представляется возможным, если учитывать близость Толстого в І930-х гг. к главной редакции «Истории Гражданской войны», которая имела в своем распоряжении соответствующие архивные материалы. Однако в этом случае необходимо признать, что выписки могли быть сделаны писателем никак не ранее начала І930-х гг., уже после выхода в свет постановления ЦК ВКП(б) от 3І июля І93І г. об издании «Истории Гражданской войны», инициатором которого был А.М. Горький.

Более всего знакомство Толстого с «Дневником» проявилось в завершающей книге трилогии «Хождение по мукам», романе «Хмурое утро» (опубликован в I940-I94I гг.), при характеристике поведения Махно накануне похода на Екатеринослав. Черпая из документа детали, воссоздавая на их основе общую картину, дополненную собственной фантазией, писатель выносит самостоятельное суждение по поводу тех фактов, которые так возмутили когда-то героя «Дневника»: «Махно гулял. В добытой после налета на Бердянск гимназической форме колесил на велосипеде напоказ всему городу, или вместе со своим адъютантом Каретником пел песни под гармонь, шатаясь по улице, или появлялся на базаре, злой и бледный, ища ссоры, но все от него прятались, зная, как легко у него из кармана штанов вылетает револьвер. Дюжие махновцы, не боящиеся ни бога, ни черта, увидев его около карусели, слезали с деревянных коней и пускались наутек. Батьке приходилось одному вместе с Каретником крутиться до одури. По всему Гуляй-Полю шли разговоры, что батька за последнее время стал много пить, и как бы не пропил армии. Но только немногие догадывались, что он хитрит. Был он хитер, скрытен, живуч, как стреляный дикий зверь» [9, с. I44].

Описывая психологическое состояние Махно, Толстой создает на страницах трилогии образ атамана, который мало соотносится с образом неуравновешенной личности, бездумного гуляки и алкоголика (а ведь именно так порой и прочитывались записи «Дневника» его публикаторами I920-х гг.): «Махно понимал, что, не прими он теперь же твердого, угодного армии решения, - конец его делу, его славе. Только два выбора было перед ним: поклониться большевикам, делать, что прикажет главковерх, и ждать, когда его в конце концов расстреляют за своевольство. Или, зарубив делегата Чугая, поднимать на Украине мужицкое восстание против всякой власти. Но вовремя ли это? Не ошибиться бы... Мысли эти были настолько тайные, 
что опасно было их высказывать даже преданным собакам Левке и Каретнику. Ему было тесно от мыслей. Армия ждала. Делегат Чугай и старикашка, мировой анархист из Харькова, ждали. Махно пил спирт, не теряя разума, нарочно дурил и безобразничал, - глаз его был остер, ухо чуткое, он все знал, все видел» [9, с. I45].

Но все же, насколько позволительно было Толстому при характеристике Махно I9I8 г. использовать факты, имевшие место в г920-м? Не будем забывать, что речь идет о художественном произведении, где писателю было необходимо создать полноценный образ исторической личности. Для этого в трилогии весь период махновщины сжат до нескольких месяцев, на протяжении которых характер героя показан в его стремительном развитии.

Однако был в работе Толстого над образом Махно в трилогии «Хождение по мукам» и случай откровенного отказа от достоверных, документально подтвержденных фактов. Речь идет об упомянутом в произведении конце атамана Н.А. Григорьева, убитом махновцами в июле I9I9 г. В романе «Хмурое утро», характеризуя состояние тылов армии А.И. Деникина, Толстой писал: «Махно, после того как ухитрился лично застрелить своего главного соперника - атамана Григорьева, открыто объявил вольный анархический строй по всей Екатеринославщине, собрал тысяч пятьдесят бандитов и грозится отобрать у Деникина Ростов, и Таганрог, и Крым, и Екатеринослав, и Одессу...» [9, с. 304].

Все дело в том, что «лично» Махно в Григорьева не стрелял, и Толстому в пору работы над трилогией это было хорошо известно. В архиве писателя в ОР ИМЛИ нами был обнаружен документ, в полной мере об этом свидетельствующий. Приведем его полностью, сохраняя оригинальные орфографию и синтаксис:

\section{АКТ}

Херсонской губернии Александрийского уезда село Сентово г919 года июля $28^{\text {ro }}$ дня мы нижеподписавшиеся Командующий украинскими партизанскими войсками Батько Махно, Н-к штаба Григорий Махно, заместитель и член реввоенсовета Алексей Чубенко Член ревсовета Шпота Фома Н-к кавалерийских частей Щусь Фодор, Командир $3^{\text {го }}$ пехполка Гавриленко, Н-к пулеметных частей Фома Кожин, Н-к штаба кавчасти Чалый, Челен ревсовета Василевский Чайковский, Челен ревсовета Троян адютант Батька Махно Лю- 
тый, Член ревсовета Чучко Иван Член ревсовета Пузанов секретарь ревсовета Лещенко. Составили настоящий акт в том, что согласно постановления чрезвычайной пятерки Батько Махно Чубенко Каретников Семен Чалый и Щусь, которая постановила убить Атамана Григорьева и ликвидировать все вооруженные силы григорьевцев 28/VII-I9I9 года в селе Сентово на сельском сходе в присутствии всего сельского схода был убит Атаман Григорьев и его телохранитель и тяжело был ранен командир махновских частей Колесник того же 28/VII-I9 были разоружены все Григорьевские части. Вопреки постановления чрезвычайной пятерки Атаман Григорьев был убит Чубенком а не Каретником как это было постановлено пятеркой. Телохранителя Атамана Григорьева убил Батько Махно и Колесника ранил тоже Батько Махно. Руководство по разоружению частей провели Щусь, Кожин и Григорий Махно.

Подписали

Б. Махно Г. Махно А. Чубенко Шпота Щусь Каретник Гавриленко Кожин Чалый Василевский Троян И. Лютый Чучко Пузанов Секретарь ревсовета Лещенко 5

Документ выполнен на сложенном вчетверо относительно ветхом листе бумаги с водяными знаками, истерт по местам сгибов. Его орфография и синтаксис, а также разные чернила, употребленные подписантами, косвенно указывают на подлинность Акта. Хотя, безусловно, он требует более детальной экспертизы. О том, как документ попал к Толстому, мы ничего не знаем. Хранится он вместе со сделанной в I9I9 г. фотографией, на которой запечатлены сам Махно и его ближайшие соратники: И.Е. Лютый, А.М. Ольховик, П. Пузанов, И.М. Новиков, П.Ф. Белочуб, В.В. Куриленко, Ф.У. Щусь, Я.В. Озеров и А.В. Чубенко ${ }^{6}$

Николай (Никифор) Александрович Григорьев (г885-19г9), офицер царской армии, участник Русско-Японской и Первой мировой войн, принадлежит к наиболее колоритным личностям периода Гражданской войны. Полковник Украинской народной армии, сформированной Центральной радой, Григорьев в начале І9І9 г. перешел на сторону советской власти. С апреля он возглавлял 6-ю Украинскую советскую дивизию Украинской советской армии. К числу его громких побед относится взятие Одессы вес-

5 ОР ИМЛИ. Ф. 43. Оп. г. Ед. хр. г2г. Л. 30.

6 ОР ИМЛИ. Ф. 43. Оп. г. Ед. хр. г2т. Л. 3І. 
ной І9І9 г. В это время находившийся в городе Алексей Толстой, будущий автор трилогии «Хождение по мукам», отправился в свое четырехгодичное эмигрантское странствие. Впоследствии он, видимо, не забыл, что был изгнан из страны войсками под руководством Григорьева, сохранив интерес к личности и деяниям этого человека. Не сделав его героем трилогии (хотя, судя по планам, намеревался), писатель посвятил ему очерк «Атаман Григорьев» (1929), где описал в том числе и взятие Одессы.

Красным командиром Григорьев пробыл недолго, уже в мае того же I9I9 г. открыто выступив против советской власти на Украине. Однако в июне он был разгромлен выставленными против него значительными силами Красной Армии. Именно тогда Григорьев и предпринял попытку объединиться с Махно, также порвавшим, после недолгого сотрудничества, с советской властью и объявленным приказом председателя Реввоенсовета Л.Д. Троцкого от 6 июня г919 г. вне закона. Однако между Махно и Григорьевым существовали непримиримые противоречия и явный дух соперничества, что стало окончательно ясно из изданного махновцами в мае I919 г. воззвания «Кто такой Григорьев?»: «Григорьев старый царский офицер. В первые дни украинской революции он сражался за Петлюру против советского строя, затем перебежал на сторону советской власти, и против революции вообще. Что говорит Григорьев <...> он говорит, что Украиной управляют люди, распявшие Христа <..> Братья! Разве вы не слышите в этих словах мрачного призыва к еврейскому погрому?» [I, с. II2-II3].

О политике Махно в отношении Григорьева и причинах убийства атамана писал П.А. Аршинов: «Григорьев был несомненно контрреволюционер и авантюрист, но район и масса, им руководимые, были революционны. Их-то и решил Махно включить в общее число революционных сил. Сделать это можно было, лишь насильственно удалив Григорьева и его штаб. Махно с присущей ему резкостью и прямотой решил публично разоблачить и убить Григорьева <...> Чтобы найти к нему свободный доступ, Махно вступил с ним и его отрядами в связь, якобы для объединения всех партизанских сил» [I, с. I32-I33].

Однако другой махновец, И. Теппер (Гордеев), со ссылкой на легендарного Левку Задова описывал ситуацию с убийством Григорьева в ином ключе: «Сам убийца знаменитый махновский палач Левка Задов, вдохновитель контрразведки, рассказывал мне этот эпизод и из его рассказа вскрыва- 
лась истинная подоплека этого убийства. “Он мешал и батько приказал его снять”. Это звучало чем-то таким будничным, повседневным, что я пожалел о том колоссальном количестве бумаги, на которой мы (в особенности молодежь) фиксировали это убийство, как высочайший акт революции Махно» $[7$, с. 40$]$.

До настоящего времени существует несколько версий убийства Григорьева махновцами; разночтения касаются главным образом того, кто выстрелил в мятежного атамана. П.А. Аршинов называет непосредственными исполнителями приговора С.Н. Каретникова (Каретника) и самого Махно, что не соответствует фактам, изложенным в приведенном нами документе:

27-го июля г9г9 г. в селе Сентове, близ Александрии, Херсонской губернии, по инициативе Махно был созван съезд повстанцев Екатеринославщины, Херсонщины и Таврии <...> Съехалась масса крестьян и повстанцев, отряды Григорьева и части Махно <...> Докладчиками были записаны Григорьев, Махно и ряд других сторонников того или другого движения. Первым выступил Григорьев. Он призвал крестьян и повстанцев отдать все силы на изгнание большевиков из страны, не пренебрегая в этом деле никакими союзниками <...> Заявление это оказалось роковым для Григорьева. Выступавшие немедленно после него махновец Чубенко и Махно указали на то, что борьба с большевиками может быть революционной только в том случае, если она ведется во имя социальной революции. Союз с злейшими врагами народа - с генералами - будет преступной авантюрой и контрреволюцией. Затем Махно публично, перед всем съездом, потребовал Григорьева к немедленному ответу за чудовищный погром, совершенный им в мае мес<яце> І9г9 г. в г. Елисаветграде, и за ряд других антисемитских действий <...> Последний увидел, что дело принимает для него страшный конец. Он схватился за оружие. Но было уже поздно. Семен Каретник - ближайший помощник Махно - несколькими выстрелами из «кольта» сбил его с ног, а подбежавший Махно с возгласом «Смерть атаману!» тут же дострелил его [I, с. I33-I34].

О расстреле Григорьева и расправе над григорьевцами известно также из показаний Алексея Васильевича Чубенко, данным после его ареста в ГПу, и его же ныне опубликованного «Дневника». Занимавший различные посты в махновской армии (командир отряда, начальник штаба, председатель 
различных комиссий, адъютант атамана и начальник армейской подрывной команды), Чубенко в г92І г. окончательно перешел на сторону советской власти. В своем «Дневнике» он подробно описал сельский сход в Сентове в июле I919 г. и свою роль в «разоблачении» Григорьева. Именно он выступил перед жителями села с речью об измене Григорьева («Я стал им объяснять, что “хотя мы с Григорьевым временно в контакте, но, все-таки, я вам скажу, что Григорьев - контрреволюционер, и что Григорьев царский слуга-офицер, и у него до сих пор в глазах блестят его золотые погоны” $[4$, с. 763]), что послужило началом расправы над ним. О дальнейшем Чубенко писал:

Я, как только зашел в помещение сельского совета, то зашел за стол и вынул из кармана револьвер «библей» и поставил его на боевой взвод. Это я $<$ с>делал так, чтобы Григорьев не заметил, и <так>, стоя за столом, держал в руке револьвер.

Когда зашли все остальные, то Григорьев стал около стола <на>против меня, а Махно - рядом с ним с правой стороны; Каретников - сзади Махно; с левой стороны Григорьева стал<и> Чалый, Троян и Липеченко, Колесник и Григорьева телохранитель. Григорьев был вооружен двумя револьверами системы «парабеллум»: один у него был в кобуре около пояса, а другой привязан ремешком к поясу и заткнут за голенище.

Как только все вошли в помещение, то Григорьев, обращаясь ко мне, стал говорить: «Ну, сударь, дайте объяснение: на основании чего Вы говорили это крестьянам?»

Я стал ему по порядку рассказывать основание того, что я говорил $<\ldots>$

Григорьев стал это отрицать. Я ему сказал: «Так Вы еще отрицаете, что Вы - не союзник Деникина? А кто же посылает делегацию к Деникину, и к кому приехали те два офицера, которых Махно расстрелял?»

Как только я это сказал, то Григорьев схватился за револьвер, но я, будучи наготове, выстрелил в упор в Григорьева и попал ему выше левой брови. В этот момент Григорьев крикнул: «Ой, Батько, Батько!», а Махно крикнул: «Бей атамана!»

Григорьев стал бежать из помещения, а я за ним и все время стрелял ему в спину. Он выскочил на двор и упал. Я тогда его добил. А телохранитель Григорьева выхватил маузер и хотел Махно убить, но Колесник стоял около 
него и схватил его за маузер и попал пальцем под курок, так что он не мог выстрелить. Махно в это время забежал сзади и начал стрелять в телохранителя: пять раз выстрелил, и пули п<р>ошли навылет и <даже> ранил своего телохранителя Колесника так, что они оба упали одновременно <...>

Когда была закончена ликвидация григорьевщины, то Махно <...> тут же сделал распоряжение о том, что бы во что бы то ни стало занять одну из железнодорожных станций для того, чтобы можно было сообщить по телефону о том, что нами убит атаман Григорьев и что григорьевщина ликвидирована. Сообщалось телеграммой: «Всем. Всем. Всем. Копия: Москва, Кремль. Нами убит известный атаман Григорьев. Подпись: Махно. Начальник оперативной части: Чучко» [4, с. 763-764].

Как видим, картина полностью соответствует той, что зафиксирована в Акте, что делает возможным признать сведения, приведенные Чубенко, верными.

Однако были ли у Алексея Толстого веские основания не доверять попавшему к нему документу и пренебречь изложенными в нем фактами? Скорее всего, он просто посчитал необходимым завершить сюжет, связанный с махновским движением, жирной точкой. А потому и уходит Махно со страниц трилогии непосредственным убийцей атамана Григорьева, что, видимо, соответствовало представлениям писателя об этом человеке, ставшем литературным героем.

Толстой дописывал трилогию «Хождение по мукам» в самом конце І930-х гг. После выхода в свет романа «Восемнадцатый год», ее второй части, прошло около десяти лет, прежде чем писатель вернулся к работе над произведением. Опубликовать «Хмурое утро» вслед за «Восемнадцатым годом» Толстой не смог по целому ряду причин, в том числе и связанных с политической обстановкой в стране, где полным ходом шла сплошная коллективизация. На этом фоне, по мнению писателя, показ крестьянского повстанческого движения на Украине и его вождя мог быть истолкован как пример народного сопротивления мероприятиям власти.

6 ноября г928 г. автор трилогии писал В.П. Полонскому, тогда редактору журнала «Новый мир», где публиковался роман «Восемнадцатый год»: «Дорогой Вячеслав Павлович, это не только мое опасение, я советовался с друзьями, я советовался у нас в Госиздате... Мне все советуют несколько 
обождать с “І9-м годом”7. Тема настолько острая, что в нынешней напряженной обстановке, - кто знает, - как будет принят роман? <...> По “І9-му году” у меня собран огромный матерьял, все наготове, но я боюсь, боюсь, и не напрасно. А ну как скажут, что здесь что-нибудь вроде кулацкой идеологии? Ведь вся I-я часть о Махно» [5, с. 67].

Через десять лет Толстому пришлось изменить свои планы. Махно появляется на страницах «Хмурого утра» только в девятой главе. Непосредственно махновщине, т. е. пребыванию у махновцев Вадима Рощина и взятию Екатеринослава, посвящены одиннадцатая и пятнадцатая главы. В восемнадцатой главе Махно лишь упоминается как убийца Григорьева. Но и в столь урезанном виде его образ в истории русской литературы, посвященной эпохе Гражданской войны, остается одним из самых ярких и запоминающихся.

\section{Список литературы}

I $\quad$ Аршинов П.А. История махновского движения (1918-І92І гг.). Берлин: Изд. «Группы Русских Анархистов в Германии», 1923. 258 c.

2 Литературное наследство. М.: Наука, 1965. Т. 74. 743 с.

3 Махно Н.И. Махновщина и ее вчерашние союзники-большевики (Ответ на книгу М. Кубанина «Махновщина»). Париж: Изд. «Библиотеки Махновцев», 1928. 62 c.

4 Нестор Махно. Крестьянское движение на Украине. 1918-г921. Документы и материалы. М.: РОССПЭН, 2006. 1000 с.

5 Переписка А.Н. Толстого: в 2 т. М.: Худож. лит., І989. Т. 2. 43І с.

6 Семанов С.Н. Под черным знаменем. Жизнь и смерть Нестора Махно. М.: Тов-во «Возрождение» Всероссийского фонда культуры, І990. 80 с.

7 Теппер (Гордеев) И. Махно. От единого анархизма к стопам румынского короля. [Киев]: Молодой рабочий, г924. І2г с.

8 Толстой А.Н. Собр. соч.: в го т. М.: Худож. лит., І982-I986. Т. 5. 584 с.

9 Толстой А.Н. Собр. соч.: в го т. М.: Худож. лит., г982-I986. Т. 6. 408 с.

Іо Эйдеман Р.П. Борьба с кулацким повстанчеством и бандитизмом. Харьков: Изд. Политуправления всех вооруженных сил Украины, 192г. 62 с. 


\section{References}

I Arshinov P.A. Istoriia makhnovskogo dvizheniia (I9I8-I92I gg.) [History of the makhnovsky movement (I9I8-I92I)]. Berlin, Izd. “Gruppy Russkikh Anarkhistov v Germanii” Publ., I923. 258 p. (In Russ.)

2 Literaturnoe nasledstvo [Literary heritage]. Moscow, Nauka Publ., I965. Vol. 74. 743 p. (In Russ.)

3 Makhno N.I. Makhnovshchina i ee vcherashnie soiuzniki-bol'sheviki (Otvet na knigu M. Kubanina "Makhnovshchina") [Makhnovism and its yesterday's allies, Bolsheviks (In response to the book "Makhnovism" by M. Kubanin)]. Paris, Izd. "Biblioteki Makhnovtsev” Publ., I928. 62 p. (In Russ.)

4 Nestor Makhno. Krest'ianskoe dvizhenie na Ukraine. I9I8-I92I. Dokumenty i materialy [Nestor Makhno. The villagers' movement in Ukraine. I9I8-I92I. Documents and materials]. Moscow, ROSSPEN Publ., 2006. Iooo p. (In Russ.)

5 Perepiska A.N. Tolstogo: $v 2 t$. [A. N. Tolstoy's correspondence: in 2 vols.]. Moscow, Khudozh. lit. Publ., I989. Vol. 2. 43I p. (In Russ.)

6 Semanov S.N. Pod chernym znamenem. Zhizn' i smert' Nestora Makhno [Under the black banner. Life and death of Nestor Makhno]. Moscow, Tov-vo "Vozrozhdenie" Vserossiiskogo fonda kul'tury Publ., I990. 80 p. (In Russ.).

7 Tepper (Gordeev) I. Makhno. Ot edinogo anarkhizma k stopam rumynskogo korolia [Makhno. From anarchism to the feet of the Romanian king]. [Kiev], Molodoi rabochii Publ., I924. I2I p. (In Russ.)

8 Tolstoi A.N. Sobranie sochinenii: $v$ ro t. [Collected works: in Io vols.]. Moscow, Khudozh. lit. Publ., I982-I986. Vol. 5. 584 p. (In Russ.)

9 Tolstoi A.N. Sobranie sochinenii: v ro t. [Collected works: in Io vols.] Moscow, Khudozh. lit. Publ., I982-I986. Vol. 6. 408 p. (In Russ.)

Io Eideman R.P. Bor'ba s kulatskim povstanchestvom i banditizmom [Struggle against Kulak's rebellion and banditism]. Kharkiv, Izd. Politupravleniia vsekh vooruzhennykh sil Ukrainy Publ., I92I. 62 p. (In Russ.) 